\title{
Hubungan antara Kecukupan Energi dan Status Gizi dengan Produktivitas Kerja (PT. Timur Megah Steel Gresik)
}

\section{Correlation between Energy Adequacy and Nutritional Status with Work Productivity (PT. Timur Megah Steel Gresik)}

\author{
Himaya*1, R. Bambang Wirjatmadi ${ }^{1}$
}

\begin{abstract}
ABSTRAK
Latar Belakang: Tenaga kerja mempunyai peranan sentral dalam mencapai tujuan perusahaan yang tidak dapat terlepas dari faktor produktivitas kerjanya. Beberapa faktor yang dapat mempengaruhi produktivitas kerja dari segi gizi adalah kecukupan energi dan status gizi. Kecukupan energi dan status gizi tenaga kerja yang masing-masing berbeda mengakibatkan adanya perbedaan produktivitas kerja yang dimiliki.

Tujuan: Menganalisis hubungan antara kecukupan energi dan status gizi dengan produktivitas pada tenaga kerja laki-laki bagian packing (setting mur dan baut) PT. Timur Megah Steel Gresik.

Metode: Penelitian ini merupakan penelitian observasional dengan design penelitian case control. Besar sampel yang digunakan dalam penelitian ini adalah 38 tenaga kerja. Sampel terdiri dari sampel kasus yaitu 19 tenaga kerja dengan produktivitas kurang/rendah dan sampel kontrol yaitu 19 tenaga kerja dengan produktivitas tinggi. Analisis data menggunakan uji korelasi spearman.

Hasil: Terdapat hubungan kecukupan energi $(p<0,001)$ dan status gizi berdasarkan antropometri $(p<0,001)$ dengan produktivitas kerja, namun tidak terdapat hubungan status gizi berdasarkan biokimia/status kadar hemoglobin $(p=0,172)$ dengan produktivitas kerja.

Kesimpulan: Ada hubungan yang kuat antara kecukupan energi dan status gizi berdasarkan antropometri dengan produktivitas kerja.
\end{abstract}

Kata kunci: tenaga kerja, kecukupan energi, status gizi, produktivitas kerja.

\section{ABSTRACT}

Background: Laborers have a central role in achieving company goals that cannot be separated from their work productivity factors. Several factors that can improve work productivity in terms of nutrition are energy sufficiency and nutritional status. The difference of energy adequacy and nutritional status of each labor caused differences in works productivity.

Objectives: This study aims to analyze the relation between energy adequacy and nutritional status with the productivity of labors in the packing section (setting nuts and bolts) in PT. Timur Megah Steel Gresik.

Methods: This study was an observational study with a case-control research design. The sample size used in this study was 38 workers. The sample consisted of case samples and case-control. There are 19 workers with low productivity in the case sample and 19 workers with high productivity in the control sample. Data were analyzed using Spearman correlation.

Results: The results of the analysis test showed that there was a relationship between energy adequacy $(p<0,001)$ and nutritional status based on anthropometry $(p<0,001)$ with work productivity, but there was no correlation between nutritional status based on biochemical/hemoglobin level status $(p=0.172)$ with work productivity.

Conclusions: There was a significant correlation between energy adequacy and nutritional status by anthropometry with work productivity.

Keywords: labor, energy adequacy, nutritional status, work productivity

*Koresponden:

himayamaya11@gmail.com

${ }^{1}$ Departemen Gizi Kesehatan, Fakultas Kesehatan Masyarakat, Universitas Airlangga 


\section{PENDAHULUAN}

Pada satu dasawarsa terakhir proporsi jumlah pekerja di sektor manufaktur mengalami peningkatan dari $12,5 \%$ (2006) menjadi 13,1\% (2016) $)^{1}$. Di wilayah Jawa Timur jumlah penduduk yang bekerja pada Agustus 2017 sebesar 20,1 juta orang, bertambah sekitar 985 ribu orang (5,15\%) dibandingkan keadaan Agustus $2016^{2}$. Distribusi pekerja berdasarkan jenis kelamin, untuk jumlah penduduk laki-laki yang bekerja adalah 11,9 juta, sedangkan penduduk wanita yang bekerja adalah 8,2 juta ${ }^{2}$. Kabupaten Gresik merupakan penyumbang tenaga kerja terbesar ke-9 di Jawa Timur ${ }^{1}$. Pertumbuhan industri di Kabupaten Gresik semakin meningkat, terlihat dari jumlah tenaga kerja di Kabupaten Gresik pada tahun 2015 mengalami peningkatan menjadi 577.049 orang dan pada tahun 2017 jumlah orang bekerja juga meningkat menjadi 632.529 pekerja ${ }^{1}$. Tenaga kerja merupakan salah satu asset terpenting yang dimiliki untuk menentukan perkembangan suatu perusahaan agar berjalan secara optimal ${ }^{3,4}$. Tenaga kerja mempunyai peranan sentral dalam mencapai tujuan perusahaan yang tidak dapat terlepas dari faktor produktivitas kerjanya ${ }^{5}$. Produktivitas kerja merupakan perbandingan antara hasil yang dicapai dengan peran serta tenaga kerja persatuan waktu ${ }^{6,4,7}$. Peningkatan produktivitas kerja merupakan salah satu upaya yang harus dilakukan agar perusahaan mampu bertahan dan bersaing dengan perusahaan lainnya dan untuk keberhasilan proyek ${ }^{8}$. Apabila tenaga kerja memiliki produktivitas kerja yang tinggi, perusahaan akan menghasilkan produk atau jasa yang bermutu tinggi ${ }^{9}$. Berdasarkan APO Productivity DataBook (2018), pada tahun 2016 produktivitas tenaga kerja masih belum maksimal ${ }^{10}$. Di antara negara Asean, Indonesia menempati peringkat keempat (di bawah Singapura, Malaysia, dan Thailand) dan di bawah ratarata $\mathrm{APO}^{10}$. Sebagai negara dengan penduduk terbanyak di Asia Tenggara, seharusnya Indonesia dapat memanfaatkan hal tersebut sebagai kekuatan dalam pembangunan. Kondisi kesehatan tenaga kerja dan produktivitas kerja dipengaruhi oleh beberapa faktor salah satunya adalah gizi kerja ${ }^{11}$. Menurut Ariati (2013), gizi kerja adalah gizi yang dibutuhkan oleh tenaga kerja untuk memenuhi kebutuhan sesuai dengan beban kerjanya pekerjaannya ${ }^{11}$. Tujuannya adalah agar tingkat kesehatan dan kapasitas kerja serta produktivitas kerja dapat optimal. Konsumsi pangan sangat perlu untuk diperhatikan terutama pangan sumber energi untuk mempertahankan hidup, menunjang pertumbuhan, dan melakukan aktivitas fisik sehingga energi atau biasa disebut kalori merupakan sumber tenaga utama bagi tenaga kerja dalam melakukan pekerjaan ${ }^{12}$. Asupan zat gizi yang baik adalah hal yang penting untuk pekerja terutama untuk menghasilkan produktivitas kerja yang tinggi. Berdasarkan hasil penelitian Hidayat (2014), sebagian besar bahwa tingkat konsumsi energi yang tidak tercukupi (defisit tingkat berat) sebesar 50\% produktivitas kerjanya tidak memenuhi target ${ }^{13}$. Selain tingkat kecukupan energi status gizi juga mempunyai hubungan yang signifikan dengan produktivitas kerja. Berdasarkan penelitian oleh Iswari (2014) tenaga kerja dengan status gizi tidak baik sebanyak $65 \%$ cenderung tidak produktif, sedangkan tenaga kerja dengan status gizi normal sebanyak $86,7 \%$ cenderung produktif ${ }^{14}$. Sejalan dengan penelitian Hidayat (2014) bahwa untuk tenaga kerja yang memiliki status gizi normal, yang produktivitas kerjanya memenuhi target sebesar $63,1 \%^{13}$. Hasil analisis tersebut dapat disimpulkan bahwa semakin baik status gizi seseorang, maka semakin baik produktivitas kerjanya ${ }^{13}$. Anemia pada tenaga kerja dapat menimbulkan kelelahan, pusing, badan lemah, penurunan kapasitas, dan produktivitas kerja. Beberapa penelitian telah membuktikan bahwa terdapat hubungan antara kadar hemoglobin dengan produktivitas kerja. Penelitian yang dilakukan oleh Widiastuti dan Dieny (2015) menyatakan bahwa kadar hemoglobin merupakan salah satu faktor yang paling berhubungan dengan produktivitas kerja pada pekerja, dapat disimpulkan semakin rendah kadar hemoglobin maka produktivitas kerja juga menurun ${ }^{15}$. Berdasarkan hasil penelitian yang dilakukan oleh Butar (2017), PT. Timur Megah Steel memiliki tenaga kerja lebih dari 700 orang, memproduksi berbagai jenis baut dan mur ${ }^{16}$. Perusahaan tersebut belum menyediakan penyelenggaraan makan di tempat kerja, kantin perusahaan juga belum tersedia hanya koperasi. Koperasi tersebut menjual gorengan, makanan ringan, dan perlengkapan kebutuhan sehari-hari. Pada PT. Timur Megah Steel belum menerapkan peraturan KEPMENAKER No. 608/MEN/1989 yang menyatakan bahwa untuk tenaga kerja yang bekerja selam 8 jam perlu disediakan makan dan minum paling sedikit $2 / 5$ (40\%) dari kecukupan energi sehari atau 30\% makan lengkap dan $10 \%$ selingan sehingga tidak ada energi tambahan yang dikonsumsi pekerja setelah melakukan sarapan ${ }^{17}$. Kemudian juga untuk peraturan dari SE. Mennakertrans No. SE. 01/Men/1979 tentang Pengadaan Kantin dan Ruang Makan, PT. Timur Megah Steel juga belum memfasilitasi pelayanan makan ${ }^{18}$. Oleh karena itu, mayoritas tenaga kerja di PT. Timur Megah Steel menyiapkan bekal makan siang dari rumah atau beli makanan di luar sekitar perusahaan.Terkait kondisi dari tenaga kerja terdapat sebesar $60 \%$ dari tenaga kerja bagian packaging yang memliki status gizi lebih dan terdapat $65,7 \%$ tenaga kerja yang tingkat kebutuhan energinya belum terpenuhi. Selain itu juga, terdapat $45,7 \%$ tenaga kerja yang memiliki produktivitas yang rendah/kurang dari target ${ }^{16}$. Berdasarkan masalah tersebut, peneliti perlu untuk melakukan analisa hubungan kecukupan energi dan status gizi dengan produktivitas pada tenaga kerja di bagian packing (setting mur dan baut) PT. Timur Megah Steel. Peneliti memilih bagian packing (setting mur dan baut) karena pada bagian ini pekerjaan yang dilakukan tenaga kerja secara manual tanpa bantuan mesin sehingga dapat dihitung produktivitas kerja yang dihasilkan masingmasing tenaga kerja dengan satuan waktu (8 jam/hari).

\section{METODE}

Jenis penelitian ini bersifat observasional menggunakan design penelitian case control study. Pada penelitian ini yang menjadi populasi yaitu semua tenaga kerja laki-laki yang bekerja di bagian packing (setting mur dan baut) PT. Timur Megah Steel dengan jumlah 60 pekerja. Besar sampel yang digunakan berdasarkan 
rumus case control data proporsi dalam penelitian ini adalah 38 tenaga kerja ${ }^{19}$. Sampel terdiri dari sampel kasus yaitu 19 tenaga kerja dan sampel kontrol yaitu 19 tenaga kerja. Sampel yang tergolong kasus dalam penelitian ini adalah pekerja laki-laki bagian dari populasi terpilih yang produktivitas kerjanya kurang atau rendah. Sampel yang tergolong kontrol adalah bagian dari populasi terpilih yang produktivitas kerjanya tinggi atau sesuai target atau mencapai rata-rata.Teknik pengambilan sampel untuk kelompok kasus yang digunakan yaitu simple random sampling (sampel acak sederhana) yaitu pengambilan sampel dengan cara acak tanpa memperhatikan strata di populasi. Kelompok kasus (produktivitas kurang/rendah) ini akan diambil dengan melihat hasil setting mur dan baut dari tenaga kerja yaitu <3118 pcs/hari, sedangkan untuk kelompok kontrol (produktivitas tinggi) diambil dengan melihat hasil setting mur dan baut dari tenaga kerja yaitu $\geq 3118$ pcs/hari. Hasil setting mur dan baut yang dimaksud adalah hasil dari baut, ring, dan mur yang sudah terangkai/tersetting menjadi satu. Produktivitas tinggi dijadikan sebagai kontrol karena proporsi kejadian produktivitas tinggi (53,3\%) lebih besar daripada kejadian produktivitas rendah $(46,7 \%)$ di PT. Timur Megah Steel Gresik. Pengambilan kelompok kontrol dilakukan di tempat yang sama dengan kelompok kasus. Penelitian ini dilakukan di PT. Timur Megah Steel Desa Cangkir Kecamatan Driyorejo Kabupaten Gresik pada bulan Maret hingga Mei 2019 dan telah mendapatkan sertifikat persetujuan komisi etik Fakultas Kesehatan Masyarakat Universitas Airlangga Surabaya dengan No: 132/EA/KEPK/2019.

Dalam penelitian ini, data yang dikumpulkan dibagi menjadi dua yaitu data sekunder dan data primer dengan menggunakan teknik pengukuran dan teknik wawancara. Data sekunder digunakan terlebih dahulu untuk melihat hasil produktivitas tenaga kerja dalam sehari sehingga dapat dibedakan tenaga kerja yang memiliki produktivitas kerja kurang dan tenaga kerja produktivitas kerja tinggi. Data primer diperoleh dari wawancara mengenai karakteristik tenaga kerja denggan menggunakan kuisionerdan food recall $2 \times 24$ hours untuk mengetahui asupan energi tenaga kerja. Teknik pengukuran untuk mengukur berat badan (digital scale), tinggi badan (microtoice), dan kadar hemoglobin dengan metode digital menggunakan alat Easy Touch yang dilakukan oleh tenaga medis. Usia pada tenaga kerja dikelompokkan menjadi tiga menurut Angka Kecukupan Gizi (2013) yaitu 19-29 tahun, 30-49 tahun, dan 50-64 tahun, sedangkan masa kerja adalah rentang waktu yang dihitung dari pertama mulai masuk hingga masih bekerja di suatu perusahaan ${ }^{20}$. Penilian status gizi secara langsung dapat diketahui dari antropometri dan biokimia ${ }^{21}$. Perhitungan IMT untuk mengetahui status gizi berdasarkan antropometri yang dapat diketahui dari pengukuran berat badan dan tinggi badan. Status gizi berdasarkan antropometri dikategorikan menurut Kemenkes RI (2013) yaitu kurus $\left(<18,5 \mathrm{~kg} / \mathrm{m}^{2}\right)$, normal $\left(18,5-24,9 \mathrm{~kg} / \mathrm{m}^{2}\right)$, overweight $\left(25-27 \mathrm{~kg} / \mathrm{m}^{2}\right)$, dan Obesitas $\left(>27,0 \mathrm{~kg} / \mathrm{m}^{2}\right)^{22}$. Selain itu, status gizi berdasarkan biokimia dapat diketahui dari pengukuran kadar hemoglobin darah tenaga kerja dan dikategorikan menurut Riskesdas (2013) yaitu anemia ( $<13 \mathrm{~g} / \mathrm{dl})$ dan normal $(\geq 13 \mathrm{~d} / \mathrm{dl})^{22}$. Jumlah asupan energi tenaga kerja diperoleh dari wawancara food recall $2 \times 24$ hours, kemudian dianalisis menggunakan software nutrisurvey yang dapat diketahui rata-rata jumlah asupan energi dalam satu hari. Hasil perhitungan tersebut agar dapat dicari tingkat kecukupan energinya, harus dibandingan dengan Angka Kebutuhan Gizi tenaga kerja tahun 2004 sesuai dengan aktivitas (berat) dan umur tenaga kerja yang dikoreksi berat badan dan dinyatakan dalam persen (\%) dengan kategori kurang ( $<90 \%$ dari kebutuhan), cukup (90\%-110\%), dan lebih $(>110 \%$ dari kebutuhan $)^{23,21}$. Instrumen pengumpulan data yang digunakan adalah lembar kuisioner, timbangan berat badan digital, microtoice, lembar food recall $2 \times 24$ jam, hemoglobinometer (Easy touch), dan buku foto makanan. Hubungan antar variabel pada penelitian ini menggunakan uji korelasi spearman.

\section{HASIL DAN PEMBAHASAN}

Perusahaan Timur Megah Steel merupakan salah satu perusahaan yang bergerak di sektor industri manufaktur dalam pembuatan baut dan mur. Perusahaan ini teletak di Kabupaten Gresik. Tenaga Kerja di PT. Timur Megah Steel tidak seluruhnya berstatus sebagai karyawan tetap, tetapi juga terdapat karyawan kontrak dan outsourcing. Hari operasional PT. Timur Megah Steel mulai hari Senin sampai dengan hari Sabtu, dengan jam kerja 8 jam/hari.

Karakteristik tenaga kerja yang dibahas pada penelitian ini meliputi usia dan masa kerja.Distribusi tenaga kerja laki-laki berdasarkan usia dan masa kerja dapat dilihat pada Tabel 1. Pada Tabel 1 diketahui bahwa usia pada tenaga kerja yang memiliki produktivitas kurang maupun produktivitas. Tinggi paling banyak berada direntang usia 19 tahun sampai 29 tahun. Menurut Undang-undang Keternagaakerjaan penduduk yang secara resmi dapat bekerja adalah mulai usia 15 tahun sampai 64 tahun. Berdasarkan hasil dari penelitian sebesar $68,4 \%$ usia tenaga kerja termasuk dalam rentang 19-29 tahun dan tidak ada tenaga kerja yang berusia di bawah 15 tahun dan di atas 60 tahun. Hal tersebut berkaitan dengan usia produktif yaitu usia dari mulai 1554 tahun dan semakin menurun saat usia bertambah ${ }^{24}$. Usia pada pertengahan 20 tahun adalah saat kondisi kinerja fisik sedang berada pada puncaknya, yang kemudian menurun dengan bertambahnya usia dan mengalami pengurangan sebanyak $20 \%$ pada usia 60 tahun karena keterbatasan faktor fisik dan kesehatan yang mempengaruhi ${ }^{24}$. Berkurangnya kinerja fisik ini dikarenakan jumlah energi yang diperlukan oleh tubuh telah menurun seiring dengan bertambahnya usia ${ }^{25}$. Masa kerja merupakan salah satu indikator tentang kecenderungan para pekerja dalam melakukan aktivitas kerja sehingga dapat dikatakan bahwa masa kerja yang lama menunjukkan pengalaman yang lebih dari seseorang dengan rekan kerja yang lain ${ }^{26}$. Berdasarkan hasil penelitian, sebesar 50\% tenaga kerja laki-laki bagian packing (setting mur dan baut) PT. Timur Megah Steel memiliki masa kerja dalam rentang 1-5 tahun. Masa kerja yang dimiliki paling banyak pada kelompok tenaga kerja produktivitas kurang yaitu selama kurang dari 1 tahun sebesar $52,6 \%$, sedangkan untuk kelompok tenaga 
kerja produktivitas tinggi masa kerja yang dimiliki paling banyak berada pada rentang 1-5 tahun sebesar $57,8 \%$. Tenaga kerja yang memiliki masa kerja yang lama, akan memiliki banyak pengalaman dan kemampuan serta keterampilan untuk menyelesaikan pekerjaannya ${ }^{13}$. Distribusi status gizi berdasarkan antropometri dan biokimia serta tingkat kecukupan energi pada tenaga kerja laki-laki dapat dilihat pada Tabel 2.

Berdasarkan Tabel 2 dan hasil uji korelasi spearman menunjukkan bahwa ada hubungan antara status gizi dengan produktivitas kerja $(p<0,05)$. Nilai $p$ value dari status gizi dengan produktivitas kerja adalah $p<0,001$ dengan koefisien korelasinya 0,675 yang berarti ada hubungan yang kuat antara status gizi dengan produktivitas kerja. Jika dilihat dari proporsi data penelitian ini diketahui bahwa pada kelompok tenaga kerja produktivitas kurang/rendah yang memiliki status gizi kurang persentase lebih banyak yaitu sebesar $52,6 \%$, sedangkan untuk kelompok tenaga kerja produktivitas tinggi tidak ada yang memiliki status gizi kurang, tetapi sebagian besar memiliki status gizi normal $63,2 \%$ dan yang memiliki status gizi lebih (overweight dan obesitas) sebesar $36,9 \%$.

Tabel 1. Distribusi Karakteristik Tenaga Kerja Laki-laki di PT. Timur Megah Steel Gresik Tahun 2019

\begin{tabular}{|c|c|c|c|c|}
\hline \multirow[t]{2}{*}{ Karakteristik } & \multicolumn{2}{|c|}{ Produktivitas Kurang } & \multicolumn{2}{|c|}{ Produktivitas Tinggi } \\
\hline & $n$ & $\%$ & $\mathbf{n}$ & $\%$ \\
\hline \multicolumn{5}{|l|}{ Usia (tahun) } \\
\hline $19-29$ & 15 & 78,9 & 11 & 57,9 \\
\hline $30-49$ & 3 & 15,8 & 7 & 36,8 \\
\hline $50-64$ & 1 & 5,3 & 1 & 5,3 \\
\hline Total & 19 & 100 & 19 & 100 \\
\hline \multicolumn{5}{|l|}{ Masa Kerja } \\
\hline$<1$ tahun & 10 & 52,6 & 5 & 26,3 \\
\hline 1-5 tahun & 8 & 42,1 & 11 & 57,8 \\
\hline 6-10 tahun & 0 & 0 & 1 & 5,3 \\
\hline 11-15 tahun & 0 & 0 & 1 & 5,3 \\
\hline 16-20 tahun & 1 & 5,3 & 0 & 0 \\
\hline$>20$ tahun & 0 & 0 & 1 & 5,3 \\
\hline Total & 19 & 100 & 19 & 100 \\
\hline
\end{tabular}

Tabel 2. Distribusi dan Hubungan antara Status Gizi berdasarkan Antropometri dan Biokimia serta Tingkat Kecukupan Energi dengan Produktivitas Kerja pada Tenaga Kerja Laki-laki di PT. Timur Megah Steel Gresik Tahun 2019

\begin{tabular}{|c|c|c|c|c|c|}
\hline \multirow[t]{2}{*}{ Variabel } & \multicolumn{2}{|c|}{ Produktivitas Kurang } & \multicolumn{2}{|c|}{ Produktivitas Tinggi } & \multirow[t]{2}{*}{$p$ value } \\
\hline & $\mathrm{n}$ & $\%$ & $\mathbf{n}$ & $\%$ & \\
\hline Status Gizi (Antropometri) & & & & & $<0,001$ \\
\hline Kurus/Kurang & 10 & 52,6 & 0 & 0 & \\
\hline Normal & 9 & 47,4 & 12 & 63,2 & \\
\hline Overweight & 0 & 0 & 1 & 5,3 & \\
\hline Obesitas & 0 & 0 & 6 & 31,6 & \\
\hline Total & 19 & 100 & 19 & 100 & \\
\hline Status Gizi (Biokimia) & & & & & 0,172 \\
\hline Rendah/Anemia & 15 & 78,9 & 11 & 57,9 & \\
\hline Normal & 4 & 21,1 & 8 & 42,1 & \\
\hline Total & 19 & 100 & 19 & 100 & \\
\hline Tingkat Kecukupan Energi & & & & & $<0,001$ \\
\hline Kurang (<90\%) & 10 & 52,6 & 0 & 0 & \\
\hline Cukup (90-110\%) & 9 & 47,4 & 12 & 63,2 & \\
\hline Kelebihan (>110\%) & 0 & 0 & 7 & 36,8 & \\
\hline Total & 19 & 100 & 19 & 100 & \\
\hline
\end{tabular}


Pada tenaga kerja dengan status gizi kurus akan terjadi ketidakseimbangan dan keterbatasan pada cadangan gizi yang akan dirubah menjadi ATP saat beraktivitas sehingga menyebabkan tenaga kerja cenderung lebih cepat mengalami kelelahan dalam bekerja ${ }^{27}$. Asupan energi/kalori yang memenuhi kebutuhan secara berkelanjutan akan menggambarkan status gizi yang normal, sedangkan asupan energi/kalori yang tidak memenuhi kebutuhan akan mengakibatkan kekurangan zat gizi sehingga simpanan zat gizi dalam tubuh digunakan untuk memenuhi kebutuhan. Jika keadaan tersebut berlangsung lama, akan mengakibatkan simpanan zat gizi habis, penyusutan jaringan, perubahan nilai biokimia tubuh yaitu rendahnya kadar hemoglobin, dan terjadinya peningkatan hasil metabolisme seperti asam laktat dan piruvat sehingga dapat mengakibatkan perubahan fungsi tubuh diantaranya lemah, pusing, lelah, dan nafas pendek $^{28}$. Pada tenaga kerja produktivitas tinggi yang memilki status gizi lebih dikarenakan memiliki masa kerja yang lama dan tidak anemia. Menurut Siagian (2012) masa kerja merupakan salah satu indikator tentang kecenderungan para pekerja dalam melakukan aktivitas kerja sehingga dapat dikatakan bahwa masa kerja yang lama menunjukkan pengalaman dan keterampilan yang lebih dari seseorang dengan rekan kerja yang lain ${ }^{26}$. Pada penelitian ini jika diuji korelasi secara statistik menujukkan bahwa ada hubungan antara masa kerja dengan produktivitas kerja dengan $p$-value 0,034 . Selain itu, kadar hemoglobin yang normal dapat membantu metabolisme energi di otot tidak terganggu dan mencegah terjadinya penumpukkan asam laktat sehingga tidak dapat menyebabkan rasa lelah ${ }^{12}$. Hal tersebut berbeda dengan penelitan dari Farikha dan Ardyanto (2016) yang mengatakan bahwa status gizi yang normal akan meningkatkan produktivitas kerja pekerja, dengan kata lain dapat dikatakan semakin tinggi status gizi pekerja maka produktivitas kerja akan semakin menurun ${ }^{29}$. Tenaga kerja dengan status gizi lebih atau obesitas cenderung kurang ulet dan lamban dalam bekerja, sedangkan tenaga kerja yang mempunyai berat badan normal akan lebih lincah dalam bekerja ${ }^{30}$. Hal tersebut tidak berlaku pada pekerjaan bagian setting (mur dan baut) di dalam penelitian ini, sesuai dengan obervasi peneliti tidak memerlukan kelincahan, akan tetapi memerlukan tenaga (packing mur dan baut yang sudah terangkai ke dalam karung/sak) dan kecepatan (keterampilan memasangkan mur ke baut).

Tabel 3. Distribusi dan Hubungan antara Asupan Energi dan Zat Besi dengan Produktivitas Kerja pada Tenaga Kerja Laki-laki di PT. Timur Megah Steel Gresik Tahun2019

\begin{tabular}{lccc}
\hline \multicolumn{1}{c}{ Variabel } & Produktivitas Kurang & Produktivitas Tinggi & p value \\
\hline Asupan Energi & 2312,3 & & 0,005 \\
Mean & 435,8 & 2763,8 & \\
SD & 1570 & 445,7 & \\
Minimum & 3095,5 & 1918,9 & 0,036 \\
Maksimum & & 3599,4 & \\
Asupan Zat Besi & 9,8 & & 12,3 \\
Mean & 3,2 & 4,4 & \\
SD & 4,9 & 6,1 & \\
Minimum & 15,5 & 26,2 & \\
Maksimum & &
\end{tabular}

Sebagian besar pada kelompok tenaga kerja produktivitas kurang yang memiliki kadar $\mathrm{Hb}$ rendah (anemia) sebesar 78,9\%, sedangkan untuk kelompok tenaga kerja produktivitas tinggi yang memiliki kadar $\mathrm{Hb}$ rendah sebesar $57,9 \%$. Kadar $\mathrm{Hb}$ minimum ditemukan pada penelitian ini adalah $7 \mathrm{mg} / \mathrm{dl}$ dan kadar $\mathrm{Hb}$ maksimumnya adalah $17,3 \mathrm{mg} / \mathrm{dl}$. Berdasarkan hasil uji korelasi spearman menunjukkan bahwa tidak ada hubungan antara status kadar hemoglobin dengan produktivitas kerja $(p>0,05)$. Nilai $p$-value dari status kadar hemoglobin dengan produktivitas kerja adalah $p=0,172$. Hasil penelitian ini sejalan dengan penelitian yang dilakukan oleh Khasanah (2018) bahwa tidak hubungan antara kadar hemoglobin dengan produktivitas kerja ${ }^{31}$. Hasil penelitian ini tidak sejalan dengan penelitian yang dilakukan oleh Widiastuti dan Dieny (2015) yang menyatakan bahwa terdapat hubungan yang signifikan antara kadar hemoglobin dengan produktivitas kerja, yang berarti jika tenaga kerja kekurangan kadar hemoglobin maka tenaga yang dihasilkan oleh tubuh akan berkurang dan beban menjadi cepat lelah sehingga produktivitas kerja juga rendah ${ }^{15}$. Tidak ada hubungan pada penelitian ini dikarenakan sebaran data antara kejadian anemia dan tidak anemia pada tenaga kerja tidak seimbang karena sebesar $68,4 \%$ dari total dua kelompok tenaga kerja lakilaki (produktivitas kurang dan produktivitas tinggi) bagian packing (setting mur dan baut) mempunyai kadar hemoglobin yang rendah $<13 \mathrm{mg} / \mathrm{dl}$ (anemia), rata-rata kadar hemoglobin tenaga kerja adalah $11,3 \mathrm{mg} / \mathrm{dl}$. Sebagian besar dari tenaga kerja yang mengalami anemia tidak mengalami gejala pusing atau lemas sehingga tidak terlalu mempengaruhi hasil produktivitasnya. Akan tetapi, kemungkinan mempengaruhi pada hasil dari rata-rata tenaga kerja yaitu menghasilkan setting mur dan bautsebesar 3.118 pcs/hari, jika diakumulasikan dalam sebulan gaji ratarata tenaga kerja masih belum mencapai UMR yaitu Rp 3.580.370 (3.950 pcs hasil setting mur dan baut dalam sehari). Kelompok tenaga kerja produktivitas kurang 
(kurang dari rata-rata) yang memiliki kadar $\mathrm{Hb}$ rendah (anemia) sebesar $78,9 \%$ lebih besar dari kelompok tenaga kerja produktivitas tinggi (mencapai/lebih dari rata-rata) yang memiliki kadar $\mathrm{Hb}$ rendah sebesar $57,9 \%$. Sesuai dengan penelitian oleh Putri, et al. (2016) menjelaskan bahwa tenaga kerja yang tidak anemia lebih berpotensi mencapai produktivitas kerja yang tinggi dibanding dengan tenaga kerja yang mengalami anemia $^{32}$. Jika dilihat pada Tabel 3 berdasarkan uji korelasi spearman dapat diketahui bahwa ada hubungan antara jumlah asupan zat besi dengan hasil produktivitas dengan nilai $p$-value $=0,036$. Selain itu juga, ada hubungan antara asupan zat besi dengan kadar hemoglobin dengan $p$-value $=0,000$. Asupan zat besi yang kurang dapat menyebabkan menurunnya produksi jumlah dan ukuran sel darah merah, sehingga produksi hemoglobin juga menurun ${ }^{15}$. Kadar hemoglobin yang rendah dalam darah akan mempengaruhi jumlah oksigen yang diangkut menuju otot yang membutuhkan oksigen untuk mengasilkan energi ketika digunakan untuk bekerja keras ${ }^{15}$. Menurunnya produktivitas kerja akibat kekurangan asupan zat besi disebabkan oleh dua hal, yaitu berkurangnya enzim-enzim yang mengandung besi dan besi sebagai kofaktor enzim-enzim yang terlibat dalam metabolisme energi dan menurunnya hemoglobin darah sehingga metabolisme energi di dalam otot terganggu dan terjadi penumpukan asam laktat yang menyebabkan rasa lelah ${ }^{12}$. Hal tersebut dikarenakan terjadinya hipoksia yang akan menimbulkan rasa lelah, letih, lesu pada tenaga kerja yang mengalami anemia sehingga akan mengganggu produktivitas kerja, sedangkan untuk kadar hemoglobin yang normal akan meningkatakan dan mempelancar kemampuan sistem peredaran darah dan pernafasan untuk pendistribusian oksigen menuju otot-otot yang bekerja sehingga mempercepat pemulihan tubuh akibat bekerja ${ }^{15}$.

Selanjutnya,Tabel 2 juga menunjukkan bahwa sebesar $52,6 \%$ dari kelompok tenaga kerja produktivitas kurang mempunyai kecukupan energi yang kurang, sedangkan pada kelompok tenaga kerja produktivitas tinggi tidak ada yang mempunyai kecukupan energi yang kurang, tetapi sebagian besar mempunyai kecukupan energi yang cukup. Tabel 3 menunjukkan untuk rata-rata jumlah asupan energi pada kelompok tenaga kerja produktivitas kurang lebih sedikit yaitu 2312,3 kkal dibandingkan dengan hasil asupan energi pada tenaga kerja produktivitas tinggi yang lebih tinggi yaitu 2763,8 kkal. Berdasarkan hasil uji korelasi spearman menunjukkan bahwa ada hubungan antara kecukupan energi dengan produktivitas kerja $(p=<0,05)$ dengan koefisien korelasinya 0,7 yang berarti ada hubungan yang kuat antara kecukupan energi dengan produktivitas kerja. Hasil penelitian ini sesuai dengan penelitian oleh Hidayat (2014) dan Putri (2016) menyatakan bahwa ada hubungan antara kecukupan energi dengan produktivitas kerja ${ }^{13,33}$. Asupan energi yang dikonsumsi oleh tenaga kerja akan menyumbang glikogen dan oksigen untuk kontraksi otot. Glikogen sebagai penyumbang utama energi yang digunakan untuk kontaksi otot, ketika glukosa dalam tubuh menurun. Glikogen diubah menjadi glukosa dan mengalami glikolisis secara langsung yang menghasilkan asam piruvat dan ATP (adenosine triphospate) yang fungsinya untuk kontraksi otot. Dalam pembentukan tersebut, jika proses pemecahan asam piruvat tidak disuplai oksigen, akan mengakibatkan pembentukan asam laktat di otot. Asupan energi yang kurang akan mempengaruhi penurunan pasokan glikogen dan oksigen yang mengakibatkan terjadinya penumpukan asam laktat di otot sehingga menimbulkan kelelahan ${ }^{34}$. Dampak dari kelelahan pada tenaga kerja akan mengakibatkan penurunan produktivitas kerja. Salah satu cara untuk meningkatkan produktivitas kerja dengan menjaga pola konsumsi pangan. Energi sebagai sumber tenaga dalam melakukan aktivitas pekerjaan.

Penelitian ini memiliki kelebihan dari penelitian sebelumnya yaitu dilakukannya pengukuran kadar hemoglobin pada tenaga kerja laki-laki yang hasilnya menujukkan sebesar $68,4 \%$ tenaga kerja laki-laki pada bagian packing (setting mur dan baut) mengalami anemia. Selain itu, dalam penelitian ini juga mengumpulkan data karakteristik dari tenaga kerja yang memiliki hubungan dengan produktivitas kerja yaitu masa kerja. Penelitian ini memiliki kelemahan yaitu sebaran data atau besar proporsi kejadian anemia tidak seimbang atau lebih besar daripada kejadian tidak anemia pada tenaga kerja laki-laki sehingga secara uji statistik tidak berhubungan. Saran untuk peneliti selanjutnya agar menambah jumlah sampel lebih besar dan memperhatikan sebaran data atau proporsi kejadian anemia dan tidak anemia supaya dapat memiliki hubungan yang kuat sehingga mendapatkan hasil yang berkesinambungan dari keempat variabel antara kecukupan energi, masa kerja, status gizi, dan kadar hemoglobin dengan produktivitas kerja.

\section{KESIMPULAN}

Ada hubungan yang kuat antara kecukupan energi dan status gizi berdasarkan antropometri dengan produktivitas kerja. Saran bagi tenaga kerja yang memiliki kadar hemoglobin yang rendah/anemia, supaya lebih memperhatikan asupan makan terutama makanan sumber zat besi yang banyak terdapat pada lauk hewani terutama daging merah. Selain itu juga, lebih meningkatkan konsumsi sayuran hijau dan buah-buahan serta mengurangi frekuensi minum kopi/teh agar tidak menghambat penyerapan zat besi.

\section{ACKNOWLEDGEMENT}

Peneliti sangat berterimakasih kepada Kabag Packing Bag, Kepala Personalia, dan Direktur PT. Timur Megah Steel Gresik yang telah memberikan izin tempat untuk dilakukannya penelitian. Selain itu juga, pada tenaga kerja bagian packing (settingmur dan baut) yang dengan ramah bersedia menjadi responden dalam penelitian ini sehingga pengambilan data dapat terlaksana dengan baik.

\section{REFERENCE}

1. Badan Pusat Statistik. Provinsi Jawa Timur Dalam Angka. (2018).

2. International Labour Organization. Laporan Ketenagakerjaan Indonesia 2017. (2017). 
3. Olusegun., Adetayo, J., Oluwasayo, A.J., \& Olawoyin, O. An Overview Of The Effects Of Job Stress On Employees Performance In Nigeria Tertiary Hospitals. Sci. Rev. Artic. 60, (2014).

4. Aprilyanti, S. Pengaruh Usia dan Masa Kerja Terhadap Produktivitas Kerja (Studi Kasus: PT. OASIS Water International Cabang Palembang). J. Sist. dan Manaj. Ind. 1, 68 (2017).

5. Septiani, V. M. Pengaruh Pelatihan, Pengalaman Kerja, dan Promosi Jabatan Terhadap Kinerja Karyawan pada Badan Pemeriksa Keuangan Republik Indonesia Perwakilan Sulawesi Utara. J. EMBA 3, 992-1002 (2015).

6. Ardana. Manajemen Sumber Daya Manusia. in (Graha Ilmu, 2012).

7. Sulaeman, A. Pengaruh Upah dan Pengalaman Kerja terhadap Produktivitas Karyawan Kerajinan Ukiran Kabupaten Subang. Trikonomika 13, 91-100 (2014).

8. Nasirzadeh, F. \& Nojedehi, P. Dynamic modeling of labor productivity in construction projects. Int. J. Proj. Manag. 31, 903-911 (2013).

9. Tarwaka. Ergonomi Industri. (Harapan Press, 2010).

10. Asian Productivity Organization. APO Productivitity Databook 2018. (Kelo University Press Inc, 2018).

11. Ariati, N. N. Gizi dan Produktivitas Kerja. J. Skala Husada 10, 214-218 (2013).

12. Almatsier, S. Prinsip Dasar Ilmu Gizi. (PT Gramedia Pustaka, 2009).

13. Hidayat, E. Kebiasaan Sarapan Hubungannya Dengan Produktivitas Kerja Karyawan PT. Samick Indonesia. (Institut Pertanian Bogor, 2014).

14. Iswari, D. A. P. Hubungan Antara Kebiasaan Sarapan Dan Status Gizi Dengan Produktivitas Kerja Pada Pekerja Wanita Di Konveksi Rizkya Batik Ngemplak Boyolali. (Universitas Muhammadiyah Surakarta, 2014).

15. Widiastuti, S. \& Dieny, F. F. Faktor determinan produktivitas kerja pada pekerja wanita. J. Gizi Indones. Indones. J. Nutr. 4, 28-37 (2015).

16. Butar, M. M. Hubungan Status Gizi, Tingkat Asupan Energi, Beban Kerja dengan Produktivitas Kerja. (Universitas Airlangga, 2017).

17. Peraturan Menteri Tenga Kerja dan Transmigrasi No. Per.608/MEN/1989. Tentang Pemberian Makan Tenaga Kerja.

18. Surat Edaran Menteri Tenaga Kerja dan Transmigrasi No.01/MEN/1979. Pengadaan Kantin dan Ruang Makan.

19. Kuntoro. Metode Sampling dan Penentuan Besar Sampel. (Pustaka Melati, 2010).

20. AKG. Angka Kecukupan Gizi Energi, Protein, Lemak, Mineral dan Vitamin yang di Anjurkan Bagi Bangsa Indonesia. (2013).

21. Supariasa, I.D.N., Bakri, B., Fajar, I. Penilaian Status Gizi. (Penerbit Buku Kedokteran EGC, 2012).

22. RISKESDAS. Hasil Utama Riset Kesehatan Dasar 2018. Kementrian Kesehat. Republik Indones. 1,
1-200 (2018).

23. AKG. Angka Kecukupan Gizi Energi, Protein, Lemak, Mineral dan Vitamin yang di Anjurkan Bagi Bangsa Indonesia. (2004).

24. Kumbadewi, L. S., Suwendra, I. W. \& Susila, G. P. A. J. Pengaruh Umur, Pengalaman Kerja, Upah, Teknologi, dan Lingkungan Kerja Terhadap Produktivitas Karyawan. J. Bisma Univ. Pendidik. Ganesha Jur. Manaj. 4, 1-11 (2016).

25. Budiono, S., Jusuf, RMS., Pusparini, A. Bunga Rampai Hiperkes dan Keselamatan Kerja.

(Badan Penerbit Universitas Dipenogoro, 2003).

26. Siagian, S. Manajemen Sumber Daya Manusia. (Bumi Aksara, 2012).

27. Suma'mur. Higiene Perusahaan dan Kesehatan Kerja. (Sagung Seto, 2009).

28. Atiqoh, J., Wahyuni, I. \& Lestantyo, D. FaktorFaktor yang Berhubungan dengan Kelelahan Kerja pada Pekerja Konveksi Bagian Penjahitan di CV. Aneka Garment Gunungpati Semarang. J. Kesehat. Masy. 2, 119-126 (2014).

29. Farikha, R. R. P. \& Ardyanto, D. Hubungan Status Gizi, Karakteristik Individu Dengan Produktivitas Pekerja Sorting Dan Packing. Indones. J. Occup. Saf. Heal. 5, 71 (2017).

30. Novianti, B. Hubungan Antara Usia, Status Gizi, Motivasi Kerja, Dan Pengalaman Kerja Dengan Produktivitas Kerja Operator Bagian Perakitan Di PT. X. J. Kesehat. Masy. 5, 79-88 (2017).

31. Khasanah, U. \& Nindya, T. S. Hubungan Antara Kadar Hemoglobin dan Status Gizi dengan Produktivitas Pekerja Wanita di Bagian Percetakan dan Pengemasan di UD X Sidoarjo. Amerta Nutr. 2, 83-89 (2018).

32. Anggia, D., Putri, D., Hartanti, R. I., Dewi, A. \& Sujoso, P. Faktor-Faktor yang Berhubungan dengan Produktivitas Kerja Pekerja Wanita Penyadap Karet di PDP Gunung Pasang Kabupaten Jember. Artik. IIm. Has. Penelit. Mhs. 2016 (2016).

33. Putri, Y. N. Hubungan Tingkat Kecukupan Zat Gizi, Kebiasaan Sarapan, Dan Status Gizi Terhadap Produktivitas Kerja Pegawai Bagian Sewing PT. Pintu Mas Garmindo. (Institut Pertanian Bogor, 2016).

34. Arini Rahmatika Sari \& Lailatul Muniroh. Hubungan Kecukupan Asupan Energi dan Status Gizi dengan Tingkat Kelelahan Kerja Pekerja Bagian Produksi (Studi di PT. Multi Aneka Pangan Nusantara Surabaya). Amerta Nutr. 1, 275-281 (2017). 